\title{
CIRCULATORY EFFECTS OF ENFLURANE IN NORMOCARBIC HUMAN VOLUNTEERS
}

\author{
Paul R. Levesque, M.D., Veronica Nanagas, m.D., Carolyn Shanks, B.A. \\ and Shiro Shimosato, M.D. ${ }^{\circ}$
}

RECENT STUdies have revealed that enflurane (Ethrane $\left.{ }^{\circledR}\right)$ or 1,12- trifluoro-2chlorethyl difluoromethyl ether is a potent anaesthetic in both animals and man. ${ }^{1,2,3}$ Dobkin and his associates have reported that circulatory dynamics and cardiac rhythm remain relatively stable during enflurane anaesthesia in man, ${ }^{1}$ but their findings are complicated by preanaesthetic medication, induction agents, muscle relaxants, surgical trauma, controlled respiration, and respiratory alkalosis. Accordingly, the present study was designed to obtain information on the haemodynamic effects of enflurane in man at constant carbon dioxide tension.

\section{METHODS}

Ten male volunteers ranging in age from 21 to 35 years were interviewed and informed consent obtained. The procedures were approved by the Committee on Human Experimentation, Clinical Study Unit, Tufts University School of Medicine and New England Medical Center Hospitals. Each volunteer was admitted to the Clinical Study Unit three days prior to the study for complete history, physical examination, and laboratory tests, including electrocardiogram, chest X-ray, haematocrit, haemoglobin, creatinine, blood urea nitrogen, bilirubin, SGOT, SGPT and LDH, prothrombin time, alkaline phosphatase, sedimentation rate, and urine analysis. To prevent control of ventilation by positive pressure being a factor during the study, the volunteers were trained to use the ventilator. On the day following admission, they were instructed in the use of the Bennett anaesthesia ventilator. Tidal volume and frequency of respiration were set according to the Radford nomogram and the frequency was adjusted to achieve normal arterial $\mathrm{pH}$ and $\mathrm{PaCO}$.. The values obtained were noted.

On the morning of the experiment, after fasting for at least nine hours, the trained volunteer was brought to the study room. The radial artery was cannulated. A venous catheter (\#18 Sorensen) was inserted into the right ventricle through the right basilic vein for measurement of right ventricular end-diastolic pressure. Four surface EKG electrodes were applied. Needle electrodes were placed to obtain bipolar EEG tracings.

From the Department of Anesthesiology, Tufts University School of Medicine and New England Medical Center Hospitals, Boston, Mass. 02111.

Supported by Grant HE-01711 from the National Heart Institute, United States Public Health Service, and in part by Ohio Medical Products, a division of Air Reduction Company, Inc.

${ }^{\circ}$ Recipient of Research Career Development Award, 5-K04-HE42, 406-03, United States Public Health Service. 
Cardiac output was determined by means of the dye-dilution technique, using cardio-green. ${ }^{4}$ The area under the curve was integrated simultaneously by online analog computer (Sanborn 130). Methods of calculating stroke volume index, total peripheral resistance and left ventricular work per min. have been described elsewhere. ${ }^{4}$ Ventilation was then controlled by mask using the Bennett Anaesthesia Ventilator set at tidal volume and frequency obtained the preceding day.

Following a normocapnic period of thirty minutes, the control measurements of haemodynamics were made in duplicate. Anaesthesia was then induced with enflurane in nitrous oxide and oxygen (50:50 vol.\%) by mask, using a nonrebreathing system. When depth of anaesthesia had become adequate, the trachea was intubated with a cuffed tracheal tube without the use of muscle relaxants. Following intubation, nitrous oxide was discontinued and ventilation was controlled with 100 per cent oxygen. To insure normocapnoea, continuous end-tidal carbon dioxide concentration was monitored through an infrared Liston-Becker $\mathrm{CO}_{2}$ analyzer connected to a \#10 suction catheter placed near the carina. The catheter was also used to sample gas for end-tidal enflurane concentration measurement. A constant inspired concentration of anaesthetic ( $5 \mathrm{vol} . \%$ ) was delivered. Arterial blood was sampled periodically for $\mathrm{PaCO}_{2}, \mathrm{PaO}_{2}$, and $\mathrm{pH}$ by methods previously described." Arterial blood and end-tidal enflurane concentrations were determined by gas chromatography. Haemodynamic parameters were measured every 30 minutes. Anaesthesia was then discontinued and a last measurement made after recovery from anaesthesia.

\section{RESULTS}

Following 90 minutes of anaesthesia, mean values of end-tidal and arterial blood enflurane concentrations were 2.29 vol.\% (ranging from 1.81 to 3.2 ) and $23.6 \mathrm{mg}$ per $100 \mathrm{ml}$ (ranging from 19.5 to 32.7 ) respectively.

Mean values of systolic, diastolic, mean arterial, and pulse pressure decreased significantly during anaesthesia (Table I and Figure 1: $\mathrm{P}<0.01$ ), but did not differ significantly from control values following recovery from anaesthesia (Table I).

Heart rate before and during anaesthesia, and following recovery, were $65.3 \pm$ $3.7,86.6 \pm 5.1$ and $83.6 \pm 4.8$ beats/min, respectively. The average increase in heart rate during anaesthesia was 21.3 beats/min (Table I and Figure 2: $\mathrm{P}<$ $0.01)$, and was observed in all subjects $(R=0.76)$.

Stroke volume fell from an average control value of $80.7 \pm 3.2 \mathrm{ml}$ per beat to $64.36 \pm 8.8 \mathrm{ml}$ per beat $(\mathrm{P}>0.4$ ) during anaesthesia (Figure 3 ). Left ventricular work fell from $64.2 \pm 7.5 \mathrm{~kg} \mathrm{M} / \mathrm{min}$ to $44.9 \pm 7.8(\mathrm{P}>0.2)$ (Figure 3 ). These changes were not statistically significant.

Calculated total peripheral resistance fell during anaesthesia from a control value of $1.46 \pm 0.09$ to $1.013 \pm 0.15 \mathrm{dyne} \mathrm{sec} / \mathrm{cm}(\mathrm{P}<0.02)$ (Figure 4 ).

The average value for cardiac index during control and during anaesthesia was $2.80 \pm 0.21 \mathrm{~L} / \mathrm{min}$ per $\mathrm{M}^{2}$ and $3.21 \pm 0.56(\mathrm{P}>0.3)$ respectively. Changes in 
TABLE I

Mean Values of Haemodynamic Parameters Before, During and After Enflurane Anaesi hesia in 10 Healthy Volunteers

\begin{tabular}{lccc}
\hline \hline & Control S.E. & $\begin{array}{c}\text { Mean Change } \\
\text { During } \\
\text { Anaesthesia } \\
(\%)\end{array}$ & $\begin{array}{c}\text { Mean Change } \\
\text { at Recovery } \\
(\%)\end{array}$ \\
\hline $\begin{array}{l}\text { Heart rate } \\
\text { (beats/min.) }\end{array}$ & $65.3 \pm 3.7$ & $+32.6^{*}$ & $+28.0^{*}$ \\
$\begin{array}{l}\text { Systolic pressures } \\
\text { (torr) }\end{array}$ & $130 \pm 3.5$ & $-38.4^{*}$ & $-3.8 \dagger$ \\
$\begin{array}{l}\text { Diastolic pressures } \\
\text { (torr) }\end{array}$ & $69.3 \pm 3.5$ & $-32.2^{*}$ & $+4.6 \dagger$ \\
$\begin{array}{l}\text { Mean pressures } \\
\text { (torr) }\end{array}$ & $89.5 \pm 3.2$ & $-35.1^{*}$ & $+0.6 \dagger$ \\
$\begin{array}{l}\text { Pulse pressures } \\
\text { (torr) }\end{array}$ & $60.9 \pm 3.0$ & $-45.8^{*}$ & $-13.8 \dagger$ \\
$\begin{array}{l}\text { TPR (dynes'sec)/cm } \\
\text { Cardiac output }\end{array}$ & $1.462 \pm 0.085$ & $-30.7^{*}$ & $-19.1 \dagger$ \\
(liter/min.) & $5.29 \pm 0.40$ & +7.8 & $+18.5 \dagger$ \\
$\begin{array}{l}\text { Cardiac index } \\
\left.\text { (liter/min/M } / \mathrm{M}^{2}\right)\end{array}$ & $2.80 \pm 0.21$ & $(\mathrm{P}>0.3)$ & $+19.2 \dagger$ \\
$\begin{array}{l}\text { Stroke volume } \\
\text { (ml/beat) }\end{array}$ & $80.7 \pm 3.2$ & +14.8 & $+22.1 \dagger$ \\
$\begin{array}{l}\text { Left ventricular } \\
\text { work (kg m/min) }\end{array}$ & $64.2 \pm 7.50$ & -20.2 & $-1.1 \dagger$ \\
\hline
\end{tabular}

* Significant changes from the control values $(P<0.01)$

$\dagger N$ ot significant changes from the control values $(P>0.5)$.

both cardiac output and cardiac index during anaesthesia were statistically not significant (Figure 4 and Table I).

In six out of ten subjects, right ventricular and end-diastolic pressure was measured; the mean value was $4.09 \pm 2.5 \mathrm{~mm} \mathrm{Hg}$ during the control period and $5.37 \pm 1.7(\mathrm{P}>0.5)$ during enflurane anaesthesia.

Kidney function, as measured by BUN and creatinine, showed no change from control values 48 hours after the study. Electrolytes and urine analysis showed no variation from control values. Serum bilirubin measured in eight subjects remained unchanged.

The enzymes SGOT, SGPT and LDH were normal 24 hours after the study in all but two subjects. One subject had a history of chronic alcoholism, and the values of liver enzymes were SGOT 190, SGPT 145 and LDH 168 following the study, as compared to 35,30 and 135 respectively before. Another subject, who convulsed during anaesthesia showed values before and after study of 90,175 , 199 and 120, 275, 135 respectively. Haematocrit, haemoglobin and white bloodcell count showed no significant variations from control values. 
LEVESQQUe, et al.: CIRCULATORY EFFECTS OF ENFLURANE

\section{SYSTOUC \\ PRESSURE}

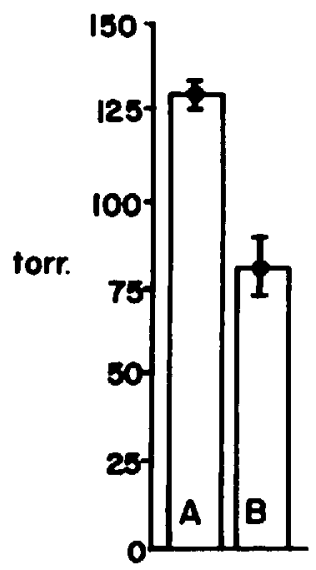

DIASTOLIC

PRESSURE
MEAN

PRESSURE
PULSE

PRESSURE

A. CONTROL.

$B=\bar{E}$ THRANE at end- fldal concentration of $2.25 \mathrm{vol} . \boldsymbol{x}$.

Figure 1. Average values ( \pm S.E.) of systolic, diastolic, mean arterial, and pulse pressure in torr before (A) and during (B) enflurane anaesthesia in 10 volunteers.

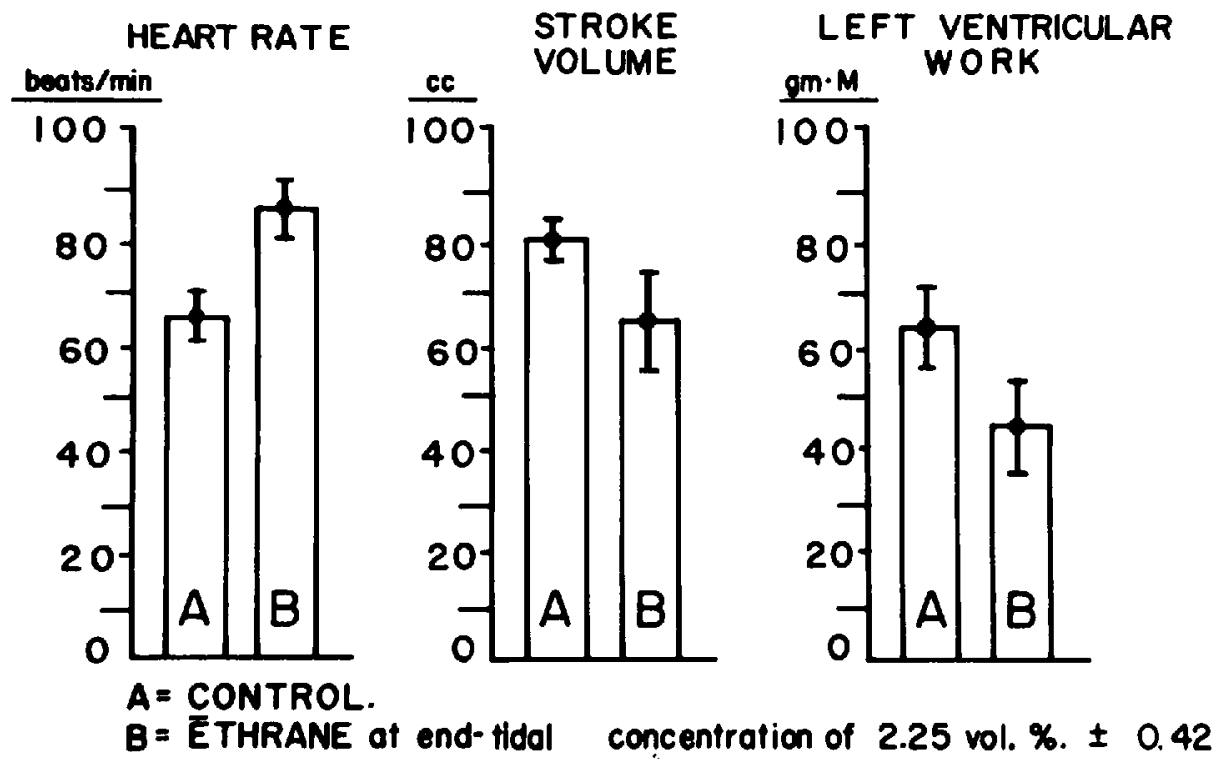

Figure 2. Mean values ( \pm S.E.) of heart rate, stroke volume and left ventricular work before (A) and during (B) enflurane anaesthesia in 10 subjects. 


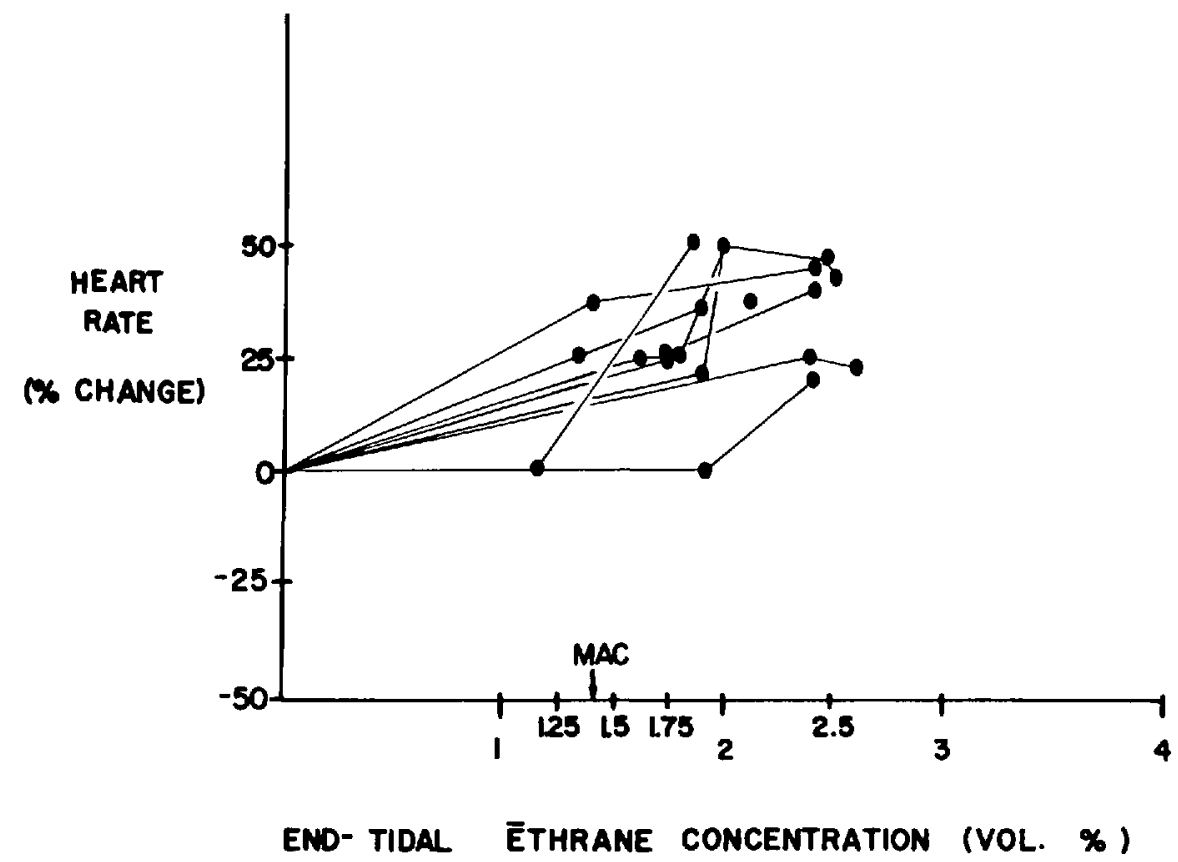

Figure 3. Relationship between per cent changes in heart rate during enflurane anaesthesia and end-ticlal enflurane concentration. Correlation coefficient, $r=0.76$.

T.P.R.

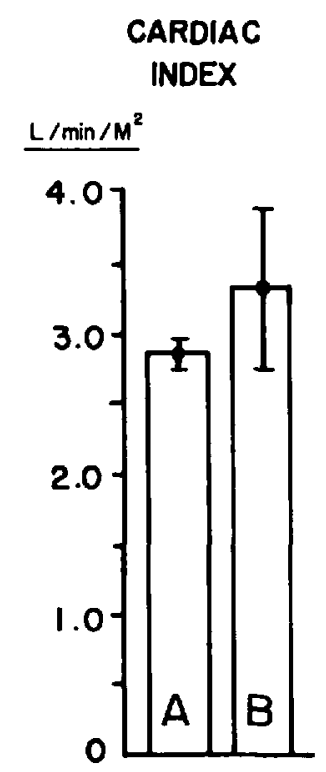

CARDIAC

OUTPUT
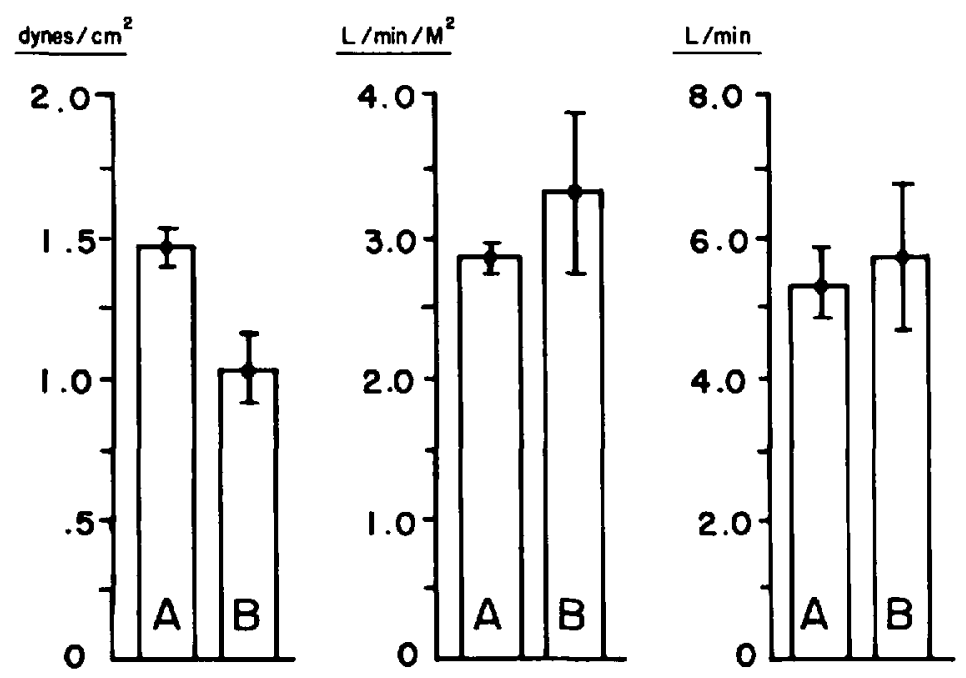

A - CONTROL.

$B$ - EThaANe at end- tidal concentration of 2.25 rol. $\%$. \pm 0.42

Figure 4. Mean values ( \pm S.E.) of total peripheral resistance (TPR), cardiac index and cardiac output before (A) and during (B) enflurane anaesthesia in 10 volunteers. 


\section{Discussion}

The singular finding of the present study is the increase in heart rate in all volunteers during enflurane anaesthesia. This finding differs from previous reports. ${ }^{1,2}$

The significant lowering of mean arterial pressure $(P<0.01)$ during anaesthesia appears to be related to a decrease in total peripheral resistance and the chronotropic effect could then explain the stability of cardiac output.

\section{SUMMARY}

The circulatory effects of enflurane were studied in ten unmedicated normocarbic volunteers during anaesthesia over a period of 90 minutes or more. Cardiac output did not change significantly during anaesthesia at a mean alveolar anaesthetic concentration of 2.3 volumes per cent and ranging from 1.8 to 3.2. Systolic, diastolic and mean arterial pressures decreased significantly, as did total peripheral resistance. The heart rate increased in all cases. Cardiac output was maintained primarily by an increased heart rate, which compensated for the decreased total peripheral resistance. At recovery, all haemodynamic parameters except heart rate returned to control levels. Minimal change in cardiac output during enflurane anaesthesia in man may be related to the combination of decreased mean arterial pressure and increased heart rate.

\section{RÉSUMÉ}

Les effets circulatoires de l'enflurane (Ethrane ${ }^{\circledR}$ ) ont été étudiés chez dix volontaires normocarbiques non prémédiqués. Le débit cardiaque n'a pas changé de façon significative durant l'anesthésie à concentration alvéolaire de 2.3 vol. pour cent ( 1.8 à 3.2 ). Les pressions artérielles systolique, diastolique et moyenne ont diminué à un taux significatif. La fréquence cardiaque augment dans tous les cas, et ceci proportionnellement à la profondeur de l'anesthésie $(r=0.76)$. La stabilité du débit cardiaque durant l'anesthésie à l'enflurane chez l'homme est due au fait que la baisse de pression artérielle est compensée par l'augmentation de la fréquence cardiaque.

\section{REFERENCES}

1. Dobkin, A.B., Heinnich, R.G., Israel, J.S., et al. Clinical and laboratory evaluation of a new inhalation agent: compound $347\left(\mathrm{CHF}_{2}-\mathrm{O}-\mathrm{CF}_{2}-\mathrm{DHF} \mathrm{Cl}\right)$. Anesthesiology 29; 275-287 (1968).

2. Linde, H.W., LAMB, V.E., Quimby, C.W., et al. The search for better anesthetic agent: clinical investigation of Ethrane. Anesthesiology 32: 555-559 (1970).

3. Shimosato, S., Chen, P.Y., Gilbert, J.B., et al. Effect of Ethrane on the performance of the left ventricle. Anesthesiology 30:351-352 (1969).

4. Etsten, B.E. \& LI, T.H. Hemodynamic changes during thiopental anesthesia in humans: cardiac output, stroke volume, total peripheral resistance, and intrathoracic blood volume. J. Clin. Invest. 34: 500-510 (1955).

5. Severinghaus, J.W. Electrodes for blood and gas $\mathrm{PCO}_{2}, \mathrm{pO}_{2}$ and blood pH. Acta Anaesth. Scand., Suppl. XI: 207-220 (1962). 